\title{
THE AESTHETIC POWER OF ANCIENT DORSET IMAGES AT QAJARTALIK, A UNIQUE PETROGLYPH SITE IN THE CANADIAN ARCTIC

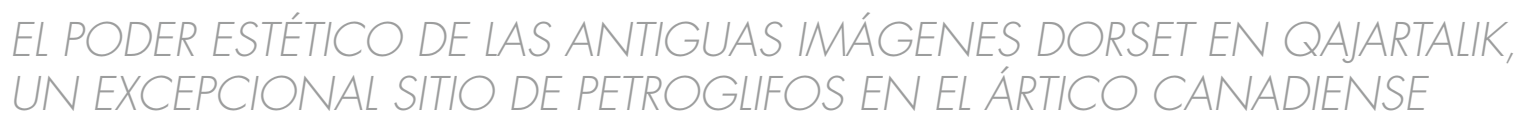

\section{Daniel Arsenault*}

At the end of the first millennium AD the Eastern Canadian Arctic became significantly warmer and the Dorset people, a nomadic society of hunter-gatherer-fishermen, had to hastily adapt to this sudden climate change. Shamanism appears to have become more important in this context of adaptation and stimulated visual art production, which became a major symbolic activity in response to the new environmental conditions. As a result, a few rock engraving sites were produced in what might have been a shamanistic context. One of those sites, the Qajartalik quarry, seems to have been the most important of all. Combining proxemic and kinesic approaches, this paper aims to discuss some aesthetic aspects proper to Qajartalik that may have been experienced by onlookers.

Key words: canadian Arctic rock art, petroglyphs, Dorset Culture, shamanism, ritual experience, aesthetics

Al final del primer milenio de nuestra era, el Ártico canadiense oriental fue significativamente mucho más cálido. Los dorset, un grupo nómada de cazadores-recolectores-pescadores, debieron adaptarse rápidamente, momento en el que el chamanismo cobró mayor relevancia, estimulando la producción de arte visual, incluyendo el arte rupestre, convirtiéndose en una actividad simbólica importante que respondía a las nuevas condiciones ambientales. Partiendo de elementos de los enfoques proxémico y kinésico, este trabajo se propone discutir algunos aspectos estéticos propios de Qajartalik que han sido experimentados por los espectadores.

Palabras clave: arte rupestre del Ártico canadiense, petroglifos, Cultura Dorset, chamanismo, experiencia ritual, estética
Nota Bene: Please note that the exact location of Qajartalik cannot be divulged here due to the fragile components of that open air rock art site, and that the Inuit community of Kangirsujuak (the closest village), their wardens, wish to see the integrity of the site respected and are therefore concerned about any uncontrolled visit of that site.

\section{INTRODUCTION}

Around the world, wherever they are located, rock art sites (whether in the form of pictographs, petroglyphs, lichenomorphs, petroforms, or geoglyphs) represent one of the most long-lasting cultural phenomena associated with human visual experience of the tangible and intangible worlds. Furthermore, most of these sites retain impressive examples of past artistic traditions and, at the same time, provide us with insights into some aspects of the world-views (Weltanschauungen) of ancient societies. Thanks to their graphic content and associated features, they can still be seen as a place of expression, especially (but not exclusively) visual expression, as a means of communication, as a locus for transmitting traditional and sacred knowledge, as a place of memory and remembrance (where the ancestors left their marks, for instance), and even as a space to be occupied in order to have a specific, singular experience or to perform a ritual.

\footnotetext{
* Daniel Arsenault, Director of the Centre interuniversitaire d'Études sur les Lettres, les Arts et les Traditions à l'UQAM (CÉLAT-UQAM), and Professor at the dept. of Art History, Université du Québec à Montréal (UQAM), Case postale 8888, Succursale Centre-Ville, Montréal, Québec, Canada H3C 3P8, email: arsenault.daniel@uqam.ca
} 
The graphic form and content, the material features of the rock support and the specific setting of a rock art site can all contribute to the site's aesthetic appeal, as Thomas Heyd and John Clegg's edited collection emphasizes (Heyd \& Clegg, 2005). In other words, the graphic content of a site, the rock outcrop bearing the images, and the place and surrounding landscape where the rock art is sited may have been-and still may begenerally appealing to the eye of the viewer. This means that every rock art site has the aesthetic potential to be appreciated for its own sake.

However, if the aesthetics-briefly defined here as the science of a qualitative assessment of the ambient world through the senses (Jimenez 1997)-of such ancient sites have not usually been taken into account by us, the archaeologists, in our analytical frameworks, maybe that is because we have not striven hard enough to develop appropriate criteria that would enable us to do so (for a history of different attitudes to the aesthetic appreciation of rock art in archaeological research, see Heyd 2005; see also Francis 2001 for some issues on style and classification in rock art). Yet it is reasonable to suppose that the aesthetic dimension of a rock art site may have played a significant role not only in the choice of an appropriate place to position the rock art, but overall in the way different persons (and/or their intangible, non-human counterparts such as the spiritual beings living on, or passing by, the site) apprehended its meaning and the complexity of its graphics. This appreciation combines both the perception and feeling that the setting and its surrounding landscape gives to onlookers. Considering that an aesthetic evaluation of this kind of archaeological site could be relevant for any rock art analysis, I argue, as some other scholars have done since the turn of the century (see Francis 2001; Ross 2001; also, the various papers in Heyd \& Clegg, 2005, as well as in Chippindale \& Nash, 2004), that this approach may help archaeologists to look differently at any given rock art site and obtain compelling new insights into how such a site was perceived in the past. In other words, these insights can shed light on ancient peoples' phenomenological understanding of the site's special nature, and even that of present-day viewers, provided that archaeologists use proper analytical tools for their analyses. It is therefore important to address this issue when we study the various components of a rock art site and try to adopt an archaeo-aesthetic reading of it, especially if we wish to better understand the specificity of such symbolically marked settings as a whole, and their uniqueness in a given cultural landscape.

In order to evaluate aesthetically the relationships between the graphic content of a rock art site and the topographical, visual and even audible features linked to it, in the following pages I will examine the site of Qajartalik as a way of introducing the criteria that may be useful for such an archaeo-aesthetic analysis. Referring to some clues and to a series of archaeological findings yielded by that site, I argue that for its creators and users, the aesthetics of its rock art might have had a strategic role in supporting and reinforcing the spiritual message they wanted to convey. More specifically, the questions that will be addressed here are:

(1) What are the formal and structural elements available to us, as rock art experts, that can contribute to the archaeological work of retrieving the aesthetic dimension of Qajartalik?

(2) To what extent has the aesthetic of Qajartalik been important in the creation of its rock art, its occasional usage and the symbolic and material exploitation of the site since it was established more than 2000 years ago?

(3) Can the aesthetic analysis of Qajartalik be used to meaningfully contribute to the reconstruction not only of the Weltanschauung of those men and women who visited the site at different times in the past, but also of the past cultural landscapes of its creators and subsequent users?

Combining elements from research into nonverbal behaviour, which codes human behaviours in terms of proxemics, kinesics and gaze, among other things, I wish to emphasize some criteria that may be useful for more appropriately discussing certain aspects of the aesthetic context of Qajartalik and its archaeological components, especially its rock art (Arsenault \& Gagnon 2002). Using the definition offered by Harrigan (2005: 137), proxemics refers to the perception and structuration of interpersonal and environmental space for individuals and groups, whereas kinesics is the analysis of the postures, gestures, stances and movements of a subject's body, heads and limbs. In addition to these approaches, analyses of the gaze refer to eye movements and directions in visual interaction (including between a subject and an object). In contrast to behavioural studies research, in an archaeological context it is impossible to directly observe and carefully study the attitudes, body movements, facial actions and other nonverbal behaviours of those who created and visited a rock art site in the past. All we can do is infer those behaviours through personal replication using the partly subjective "if... then" approach, which, roughly speaking, corresponds to the idea, "If I were standing and acting on that site in the past, then my behaviour would have been like this or like that." Still, this approach can also involve some objective criteria, as I will detail later, which can help us to narrow down, or at least better 
identify, the range of possible nonverbal behaviours occurring in relation to the aesthetic dimension of a rock art site. The criteria to be considered in this analysis are: (1) the visual symbols comprising the rock art graphic; (2) the rock outcrops, their shapes, and the layouts of the petroglyphs they bear; (3) the physical setting, with its specific topography, vistas and scenery; (4) other ambient natural phenomena (including the possibility that some may have been artificially triggered).

\section{LOCATION AND CULTURAL CONTEXT OF QAJARTALIK}

On the Northeast Coast of the Ungava Peninsula, part of the vast region of Nunavik in the Province of Quebec, is a unique area of the Eastern Canadian Arctic containing four rock engraving sites in the tundra-type environment of the "Canadian Great North." Qajartalik is the most important of the sites in terms of both graphic content and archaeological complexity. Located on Whitley Bay, near the eastern tip of a land strip joined at low tide to the north of Qikertaaluk (fig. 1)-"Great Island" in Inuktitut, the language spoken by the Inuit people of Eastern Canada-the site is named Qajartalik by the Inuit, meaning "the place where a kayak can be seen" (of course, there is no kayak to be seen here today, and no remains of such a vessel have been found in situ!).

Known for decades by the Inuit of Kangiqsujuaq and Quaqtaq, the two villages closest to Whitley Bay, the site was first reported in the early 1960s to an anthropologist, Bernard Saladin d'Anglure, by some Inuit hunters who used to camp on Qikertaaluk Island. Between 1962 and 1965, Saladin d'Anglure analysed the archaeological components of Qajartalik, the first rock art site to be discovered in the Canadian Arctic (Saladin d'Anglure 1962, 1963, 1965-1966). The anthropologist pointed out that all the 94 engravings he recorded depicted either human-like or animal-like faces, which he mistakenly called "masks." He also stated that the sample of engraved

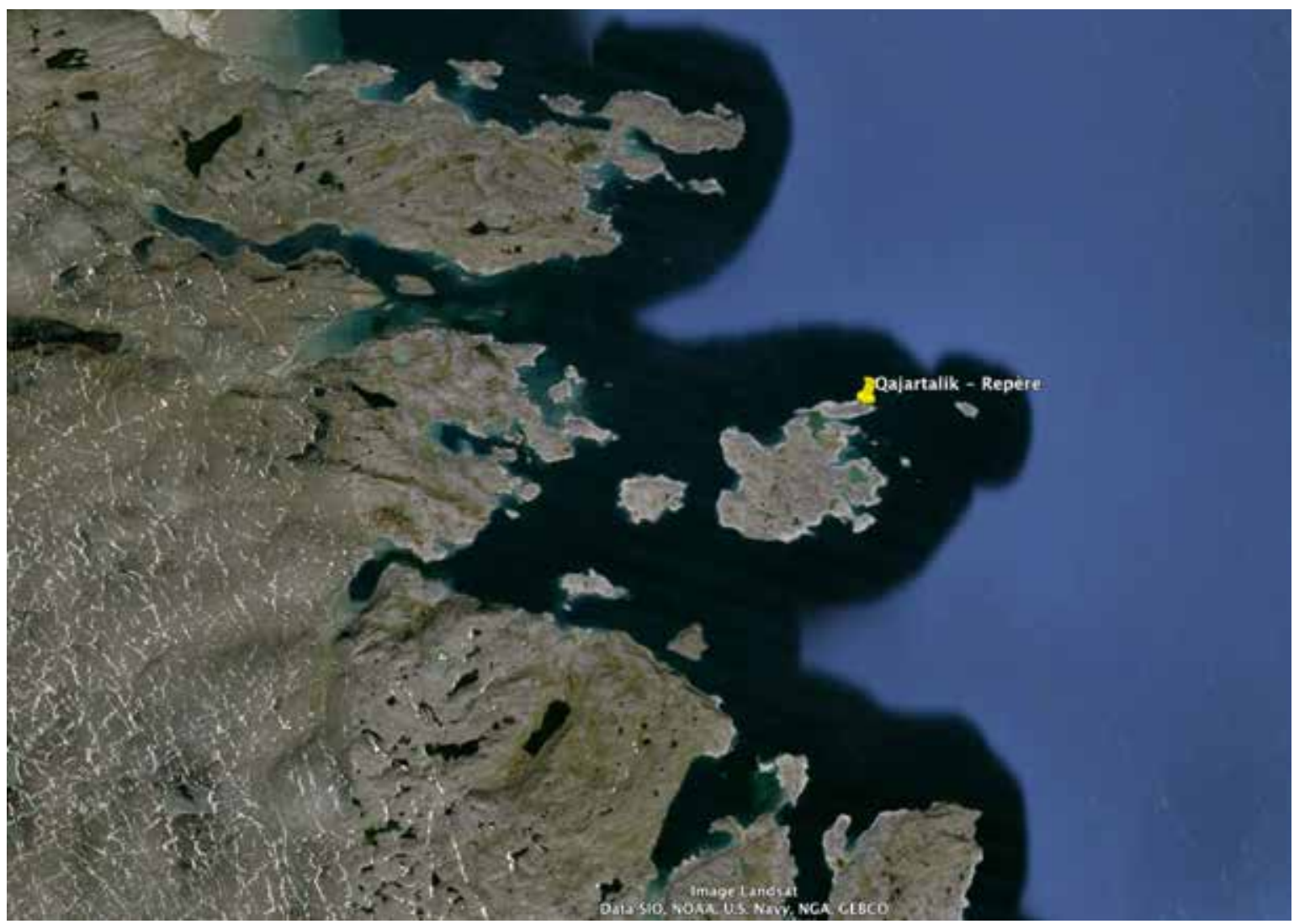

Figure 1. Map of the area where Qajartalik is located. It is one of the four rock art sites known in the Eastern part of the Canadian Arctic, an old quarry exploited since the Dorset Period, 1,000 years ago or more. Several of its steatite rock outcrops bear about 200 petroglyphs. Figura 1. Mapa del área donde se encuentra Qajartalik. Uno de los cuatro sitios de arte rupestre conocidos en la parte Este del Ártico Canadiense, es una antigua cantera explotada desde el Período Dorset, hace 1000 años o más. Varios afloramientos de esteatita presentan alrededor de 200 petroglifos. 
faces he had studied in situ was related to the Dorset artistic tradition, basing his interpretation primarily upon the petroglyphs' significant stylistic similarities with Dorset portable art (for examples of Dorset portable art, see Helmer 1986; McGhee 1987; Crandall 2004). ${ }^{1}$ The Dorset Culture endured for more than a millennium, from the last few centuries $\mathrm{BC}$ to the $13^{\text {th }}$ century $\mathrm{AD}$ Like other Paleo-Eskimo peoples, the Dorset lived as small nomadic bands of hunter-gatherers and fishermen in the harsh Arctic environment. They were followed by the direct ancestors of the present-day Inuit, a Neo-Eskimo people called Thule (McGhee 1996). ${ }^{2}$

After Saladin d'Anglure's fieldwork, this very remote site was studied periodically in situ by a few researchers, mainly for archaeological purposes (Bruemmer 1973; Arsenault \& Gendron 2007). Notably, Saladin d'Anglure and other researchers (Taylor \& Swinton 1967; Taçon 1993; Plumet 1997; Sutherland 2001; Arsenault \& Gagnon 2003; Arsenault et al. 2005) pointed out incidentally that the petroglyphs may have depicted imagery from the shamanistic domain of the Dorset people. In support of this hypothesis, it has been argued that while Dorset art production may have been inspired and stimulated by shamanism throughout its development, this appears to have intensified in the late $10^{\text {th }}$ century onward, when the Canadian Arctic became much warmer. This climatic change appears to have exerted intense pressure on the shamanistic complex, and an increase in artistic production over the following two or three centuries appears to have been one response. Thus, the rock art of Qajartalik seems to have been related to these significant environmental, social and ideological changes, and some archaeological close-up analyses of the rock outcrops appear to substantiate this assumption.

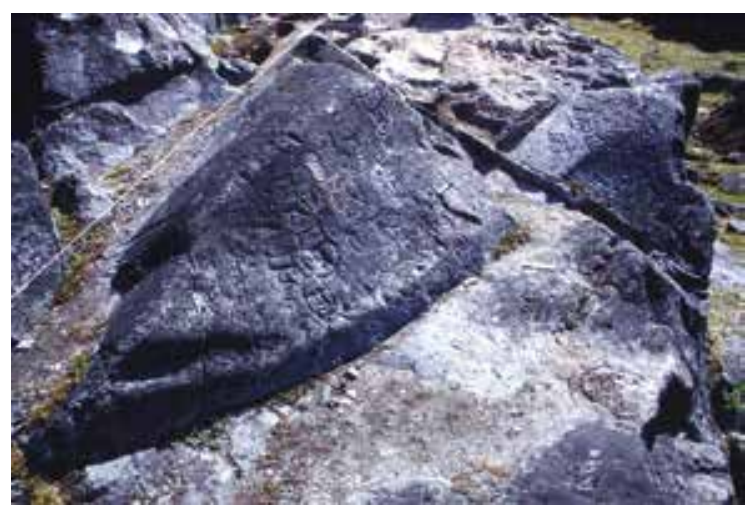

Figure 2. Qajartalik is nestled within a long rift in the upper part of a rocky slope leading to a bay (photo by the author).

Figura 2. Qajartalik está enclavado en una larga grieta en la parte superior de una pendiente rocosa que conduce a una bahía (foto del autor).

\section{A SPECIAL ROCK ART SITE}

Situated more than 15 metres above the mean sea level and at about 50 metres from the shoreline (fig. 2), Qajartalik is a complex archaeological site. It contains several rock formations of steatite ("soapstone"), the soft surface of which allowed prehistoric artists to create close to two hundred petroglyphs on its many outcrops (fig. 3). The site is also unique in that it was used as a quarry by successive groups of tool-makers and even by sculptors who visited the place during the second half of the $20^{\text {th }}$ century (Langlais 2007, 2010). ${ }^{3}$ Even though we do not know yet when Qajartalik was first quarried, we have enough archaeological evidence to argue that the steatite was an important raw material for the Dorset people, who worked it in situ to produce utilitarian objects such as oil-lamps. Later on, the Thule and the Inuit themselves would also use this quarry either for manufacturing household artefacts such as oil-lamps and cooking pots or as high quality raw material for making modern sculptures. Very close to the petroglyphs are several quarry zones, and the rough outlines of containers were even partly cut into the engraved faces during and after the Dorset occupation, altering them permanently (Arsenault et al. 2005; Arsenault 2007a) (fig. 4). However, only the Dorset people left their intriguing engravings on those rock surfaces before and after quarrying activities, in what could have been a symbolic exchange with the "spirits of the place", called Torngait by the Inuit (Arsenault 2007c).

Taken as a whole, Qajartalik can be divided into four separate sectors or activity areas that are scattered along the longitudinal axis of an oval-shaped geological rift-which is shaped like a kayak-running northwest to southwest for approximately $130 \mathrm{~m}$ (fig. 5). Sector 1

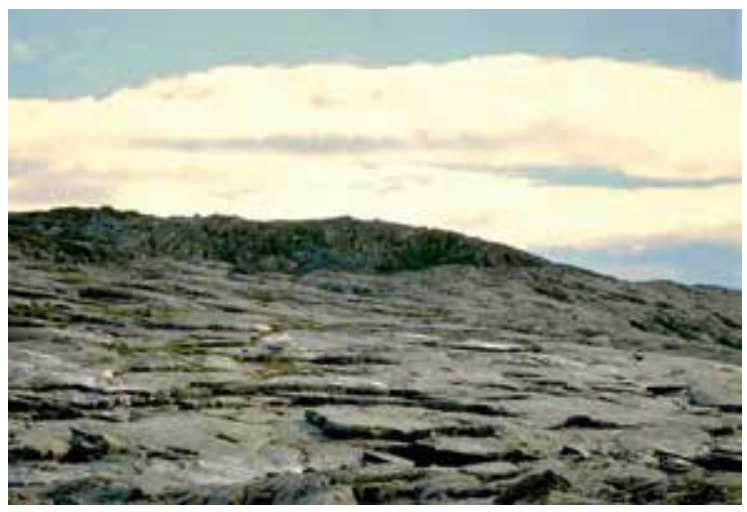

Figure 3. Some of the petroglyphs visible at Qajartalik. All the engravings illustrate human-like, animal-like or hybrid faces shown front view (photo by the author).

Figura 3. Algunos de los petroglifos visibles en Qajartalik. Todos los grabados ilustran rostros antropomorfos, zoomorfos, o rostros bíbridos exhibiendo una vista frontal (foto del autor). 


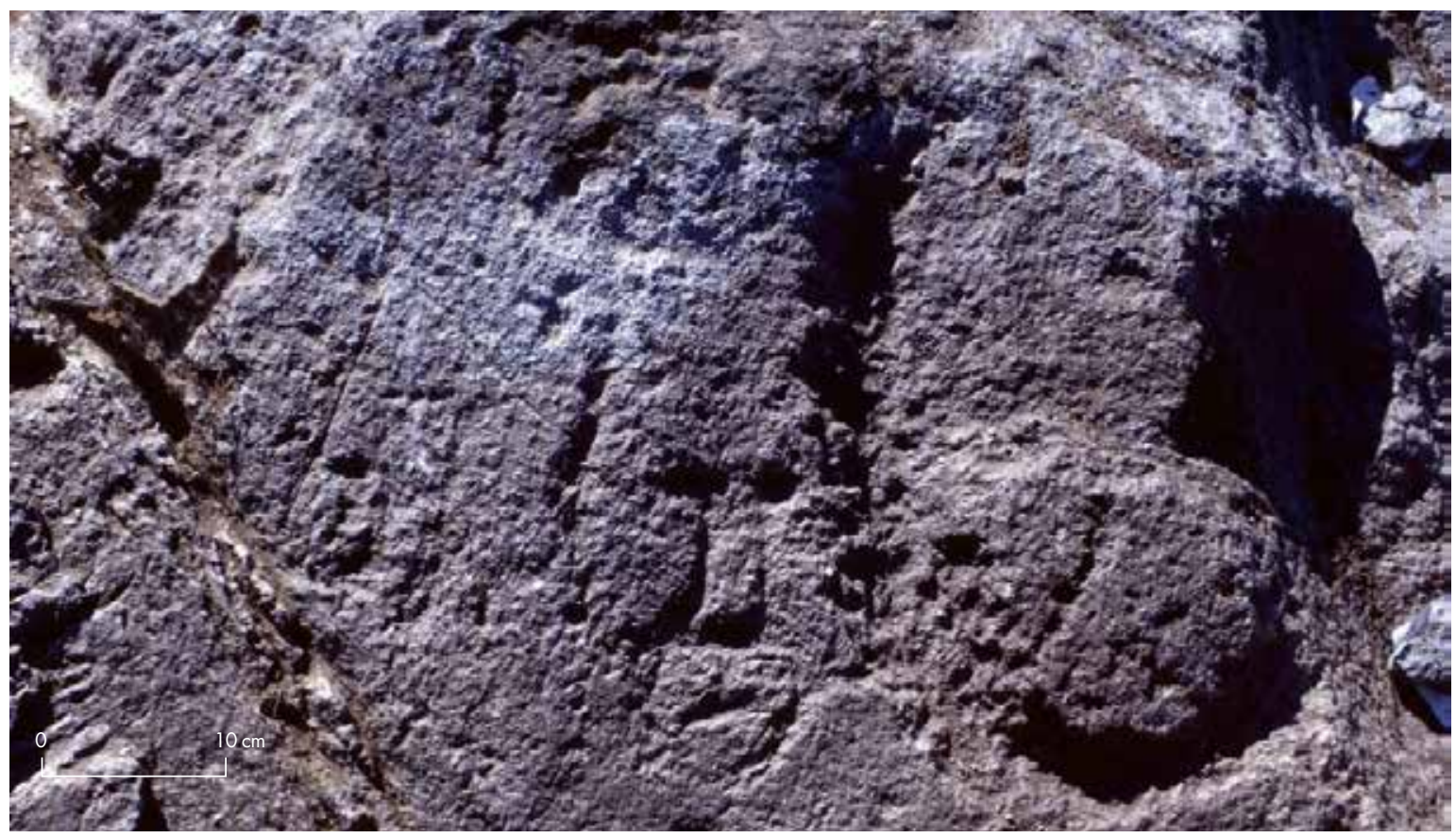

Figure 4. Because Qajartalik is both a quarry and a rock art site, one can easily note that some petroglyphs have been damaged during the making-process of an oil-lamp or a cooking pot, an extraction activity having been practiced several times during the Dorset Period onwards (photo by the author).

Figura 4. Dado que Qajartalik es tanto una cantera como un sitio de arte rupestre, se puede notar fácilmente que algunos petroglifos han sido dañados en el proceso de confeccionar una lámpara de aceite o una olla, actividad de extracción que debe haber sido practicada varias veces desde el Periodo Dorset en adelante (foto del autor).

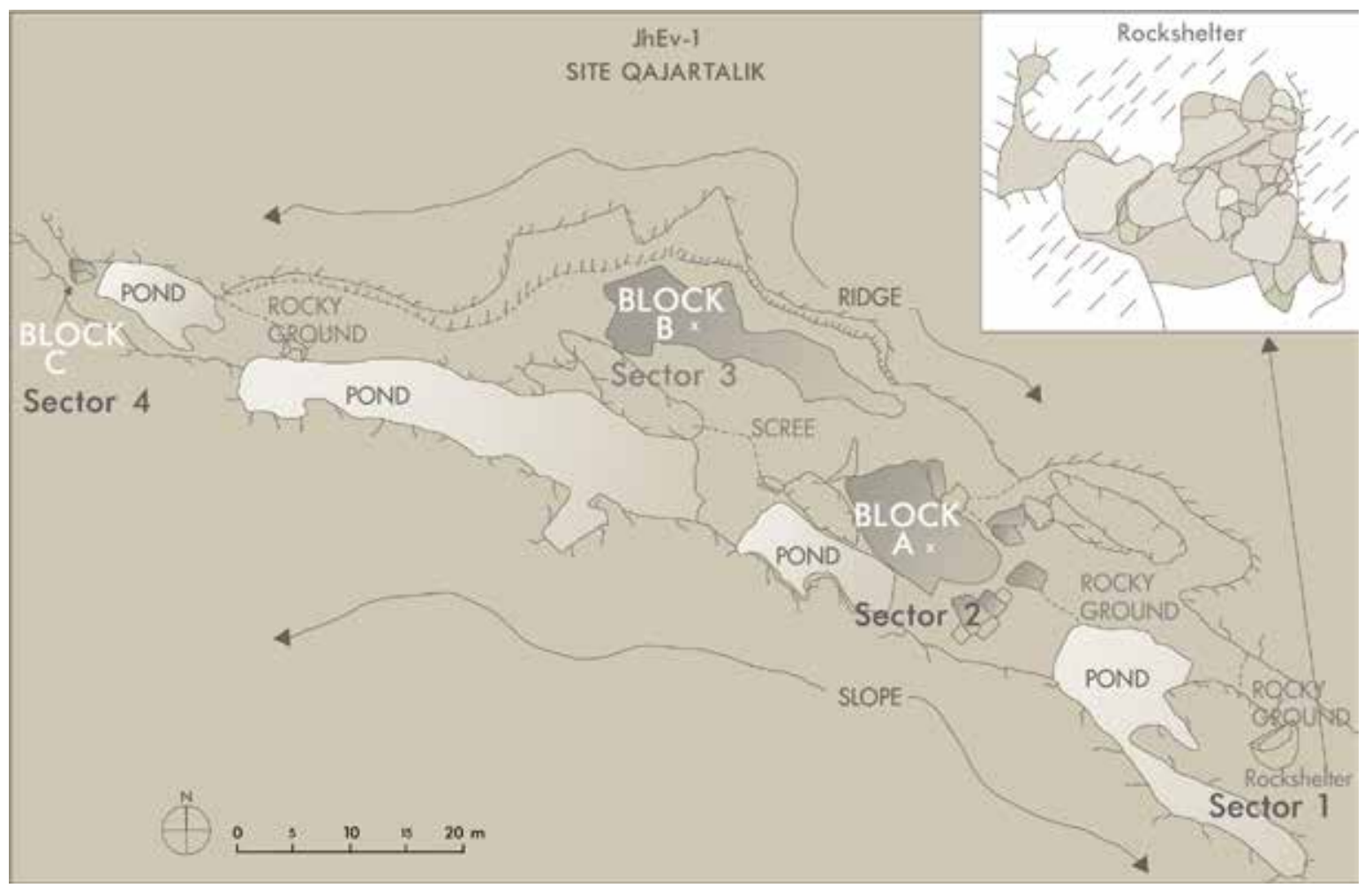

Figure 5. Map of the Qajartalik with its four distinct activities areas (sectors 1 to 4). Courtesy of Avataq Cultural Institute.

Figura 5. Mapa de Qajartalik con sus cuatro áreas de actividades distintas (sectores 1 al 4). Cortesía del Instituto Cultural Avataq. 


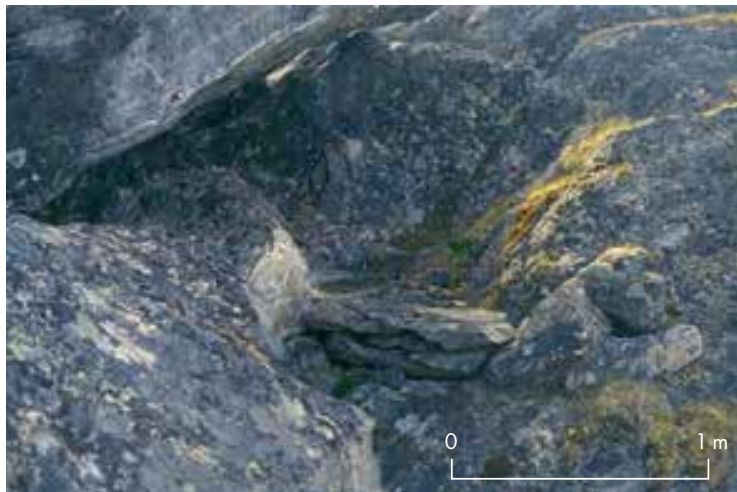

Figure 6. An artificial platform built in a rock shelter lies at the southeast end of Qajartalik. When seated on that platform, anyone can overlook the entire site and its engraved rock outcrops (photo by the author).

Figura 6. Una plataforma artificial construida en un refugio rocoso se encuentra en el extremo sureste de Qajartalik. Estando sentado en esa plataforma, se puede contemplar todo el sitio y los afloramientos rocosos grabados (foto del autor).

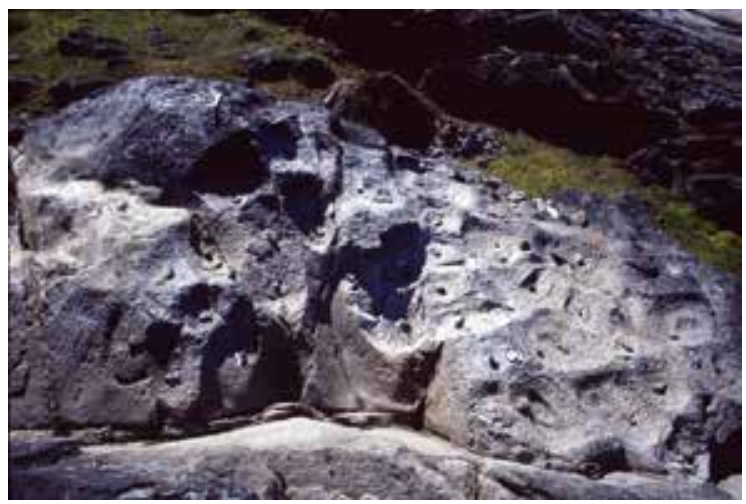

Figure 8. A vertical view of the main rock outcrop where 43 extraction zones (each indicated by a pebble) were unearthed along with six, maybe seven, new petroglyphs during the excavation of 2001. Judging from the sizes and shapes of the quarried zones, several were produced during the Dorset period but still more during the Thule exploitation of the site (photo by the author).

Figura 8. Vista vertical del principal afloramiento rocoso donde, durante las excavaciones de 2001, se desenterraron 43 zonas de extracción (cada una se indica por una piedrecilla), junto con seis, tal vez siete, nuevos petroglifos. A juzgar por los tamaños y formas de las zonas de cantera, varios de ellos fueron producidos durante el Periodo Dorset, pero aún más durante la explotación Thule del sitio (foto del autor).

is a small rock shelter containing the man-made platform 1 (fig. 6). It is the only part of the site without engravings or a quarry zone. About $30 \mathrm{~m}$ northwest is Sector 2 , the richest part of the site, with more than a hundred rock petroglyphs of various shapes and sizes, most of them visible on the main rock outcrop. This sector also contains over 40 container-extraction zones, some from the Dorset Period, others from the Thule (figs. 7 and 8) (Langlais 2007, 2010). Fifteen $\mathrm{m}$ to the

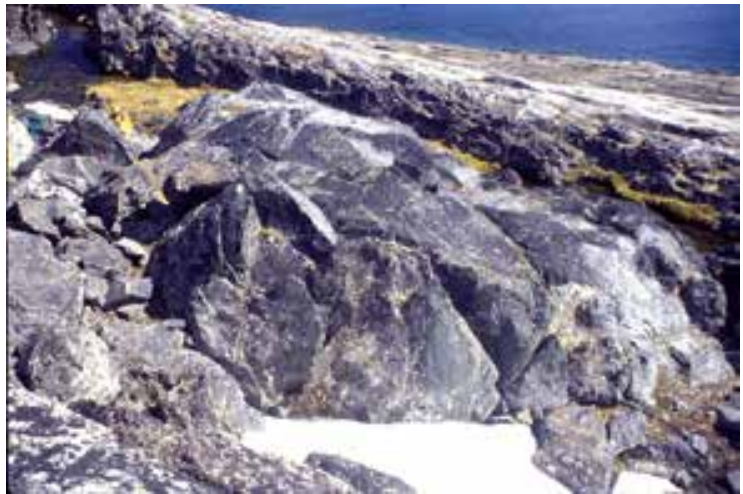

Figure 7. The Sector 2 bears about 100 distinct petroglyphs scattered on a few rock outcrops, but almost all are located on the main block (named bloc A on the map) (photo by the author)

Figura 7. El Sector 2 tiene alrededor de 100 petroglifos distintos repartidos en unos pocos afloramientos rocosos, pero casi todos se encuentran en el panel principal (denominado panel $A$ en el mapa) (foto del autor).

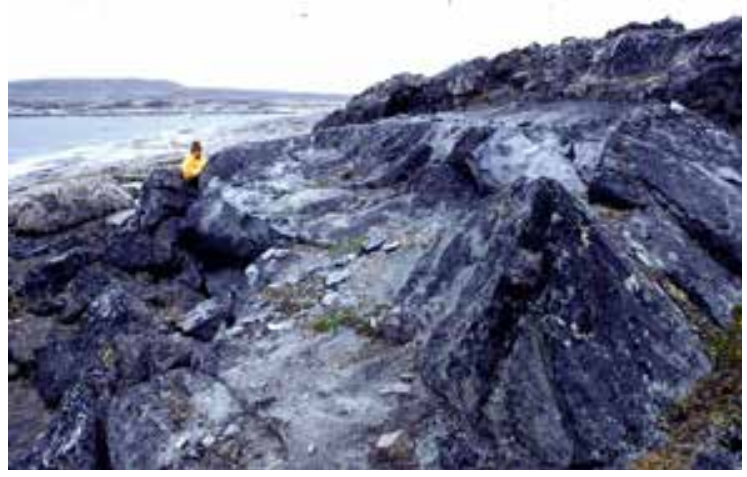

Figure 9. The predominant rock outcrop seen in the Sector 3 bears more than 80 engraved faces, including the biggest, measuring more than $70 \mathrm{~cm}$, and the smallest which is less than three $\mathrm{cm}$ in length (photo by the author).

Figura 9. El afloramiento de roca predominante visto en el Sector 3 presenta más de 80 caras grabadas, incluyendo la más grande, de más de $70 \mathrm{~cm}$, y la más pequeña, que mide menos de tres $\mathrm{cm}$ de longitud (foto del autor).

west is Sector 3, where a huge flat outcrop holds about 70 distinct engravings and a dozen ancient and several modern quarry zones (fig. 9). Finally, Sector 4, located about $80 \mathrm{~m}$ to the northwest of Sector 3, is a small irregularly-shaped boulder with only four petroglyphs on its exposed multi-faceted surface. Sectors 1 and 4 sit at the two extremities of the site's longitudinal axis.

During wintertime, snow covers almost all the rock outcrops and the surrounding ground within the rift, acting as a natural veil over the engraved surfaces but also significantly altering the vistas of the site's components. During summertime, the inner open ground may be partially covered by meltwater ponds (fig. 10), 


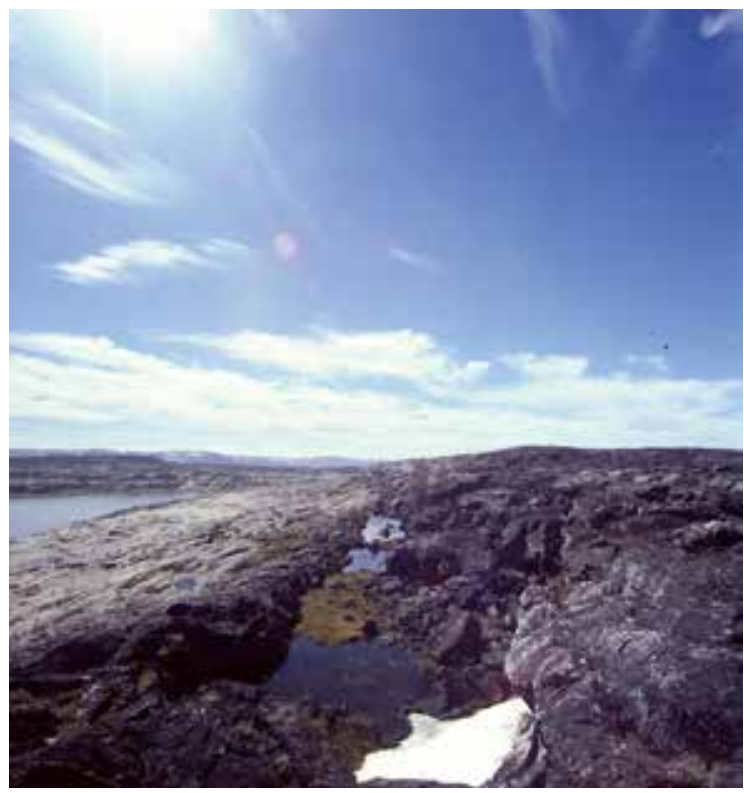

Figure 10. A general view over Qajartalik along its longitudinal axis. Note the waterholes and the remaining of the snow, despite the fact that it was summertime when the picture was taken (photo by the author).

Figura 10. Vista general sobre Qajartalik a lo largo de su eje longitudinal. Nótense los pozos de agua y el resto de la nieve, a pesar de que era verano cuando se tomó la foto (foto del autor).

limiting transit through the site to drier and more open spaces such as the tops of the two main rock outcrops that bear almost all of the petroglyphs. Thus, as the site's topography, uneven inner sector and geological features restrict the movement of viewers, they also limit their viewpoints of the site.

\section{THE AESTHETIC QUALITIES OF QAJARTALIK: KEY CRITERIA}

Now, one can ask from an archaeological perspective, what makes Qajartalik an interesting site, in terms of its aesthetics? To better answer this question, I must first mention the four criteria involved in the aesthetic appreciation of this rock art site:

(1) the engraved motifs composing the rock art graphic, that is the petroglyphs with their shapes and sizes seen as visual symbols;

(2) the rock outcrops, their shapes, and the layouts of the petroglyphs visible upon them;

(3) the physical setting, with its specific topography and the vistas and scenery it offers;

(4) other ambient natural phenomena, such as the acoustics caused by the wind, the play of light and shadow, and other phenomena that might have been generated artificially through such means as the playing of musical instruments.

\section{The petroglyphs as visual symbols}

Since the early 1960s, scientific investigation has identified over 180 different engravings of various shapes and sizes at the site, all of which, as stated above, are found in sectors 2,3 , and 4 . Whilst single engravings adorn some surfaces, many are found in groups of ten or more faces, without any specific orientation on their rock support. These petroglyphs depict primarily human-like faces, as well as a few animal-like faces (in particular, one that appears to be an owl, another a canid) and many others with features of both. All are shown in frontal view (fig. 11). While many of the faces appear life-like, making it easy for us to identify them, many others display mixed facial features that make them look neither human nor animal but rather hybrid. Such is the case, for instance, with several human-like faces bearing what may be horns or pointed ears on the top of their heads (fig. 12). ${ }^{4}$ Some of the human-like faces are also represented with slightly open, rounded mouths and inflated cheeks, and a few cases even have a series of lines protruding from under the chin. Taken together, these details suggest a subject who is blowing or singing. The engravings also include four faces with marks on their cheeks or foreheads that could be either scarifications or tattoos, both traditional practices among Palaeo-Eskimos that have been archaeologically documented (Grønnow 2012). ${ }^{5}$ In many cases, the faces have been deeply engraved, usually through pecking and grooving. A handful even used the topography of the rock surface to create facial elements (eyes, mouth, lips, nose, ears, cheeks, foreheads and chins, but no hair or beards) in relief; these faces stand out when the light hits them at an oblique angle.

The faces vary in size from $2-3 \mathrm{~cm}$ for the smaller petroglyphs to more than $70 \mathrm{~cm}$ for the larger ones. It goes without saying that the bigger the faces, the easier they are to spot on the rock surface from a distance; those measuring more than $10 \mathrm{~cm}$, and especially those with deep-grooved facial features, can be seen from a distance of about $3 \mathrm{~m}$. The smaller engravings were made by incision with a sharp-edge tool, whereas the bigger ones were usually produced through pecking and grooving with a hammerstone. A comparative analysis based on both the shapes and sizes of the engravings and their production techniques reveals at least six types of faces engraved on the site's outcrops. Thus, round-, oval- and rectangular-shaped faces, as well as shield-, teardrop- and pitcher-shaped faces can be seen on 


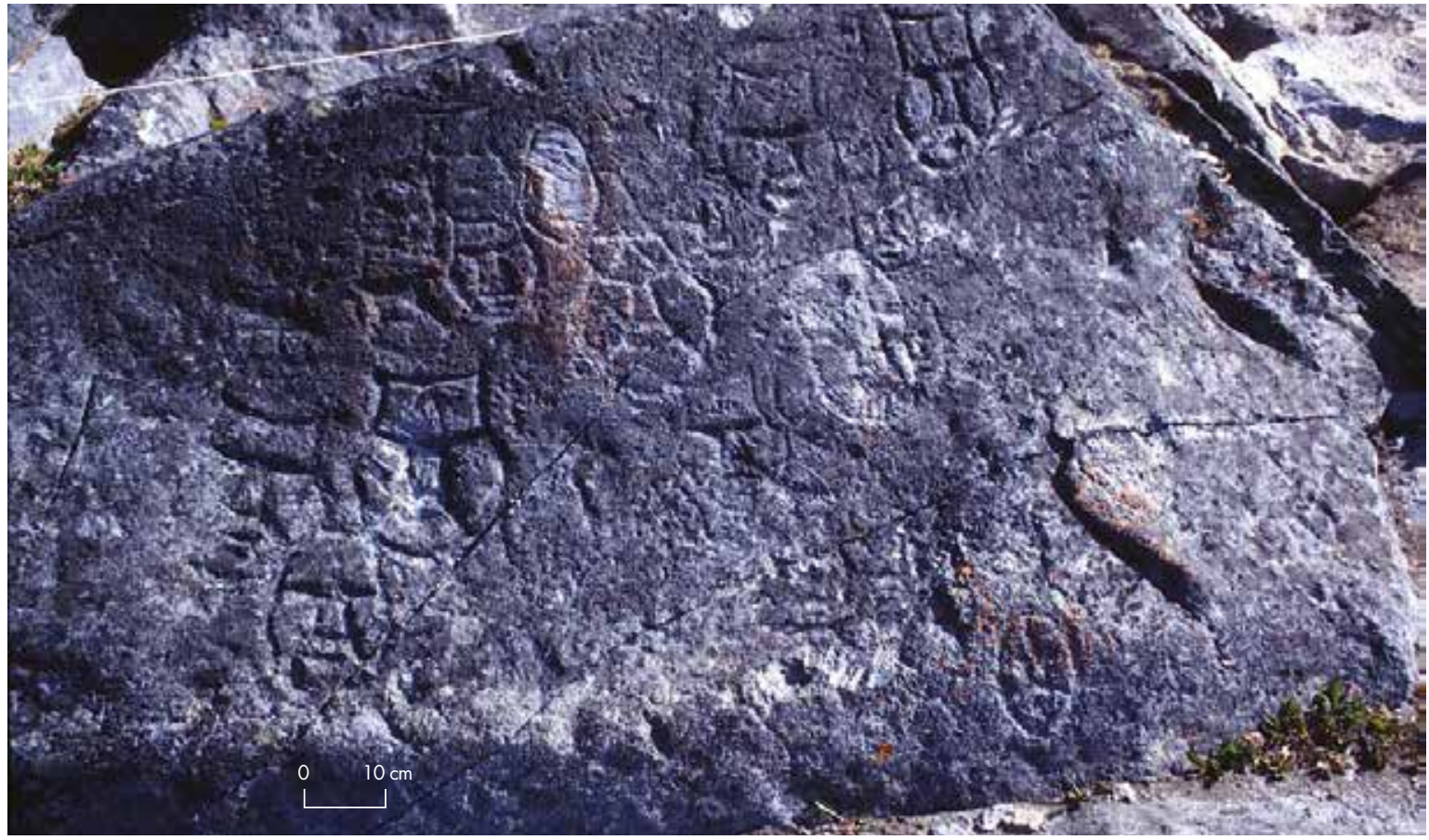

Figure 11. One of the main panels seen in Sector 2. One can notice that some engraved faces bear some additional marks beside the facial traits, probably referring to scarifications or tattoos, whereas the far-right petroglyph, visible in the upper register of the panel, has a round mouth with tiny lines protruding from under the chin, maybe suggesting the act of blowing (photo by the author)

Figura 11. Uno de los principales paneles vistos en el sector 2. Se puede notar que algunas caras grabadas tienen algunas marcas además de los rasgos faciales, probablemente refiriéndose a escarificaciones o tatuajes, mientras que el petroglifo de la extrema derecha, visible en el registro superior del panel, tiene una boca redonda con pequeñas lineas que sobresalen de debajo de la barbilla, tal vez sugiriendo el acto de soplar (foto del autor).

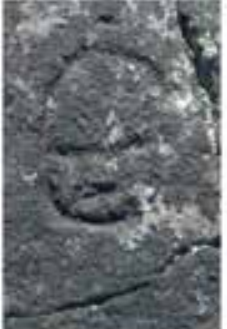

Round

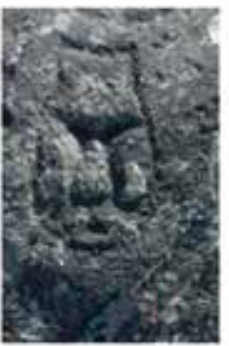

Teardrop

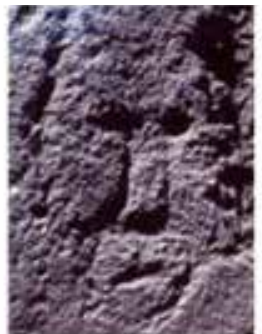

Oval

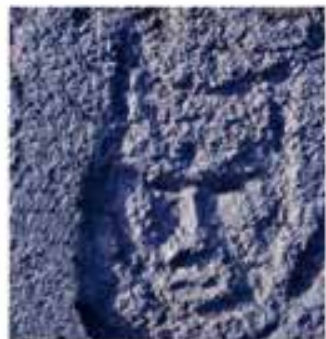

Face with its nose in relief
TYPES OF FACES

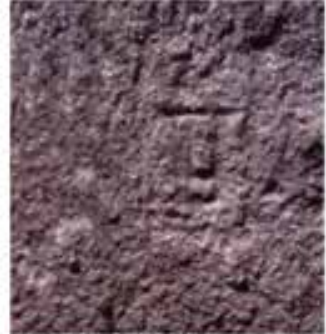

Rectangular

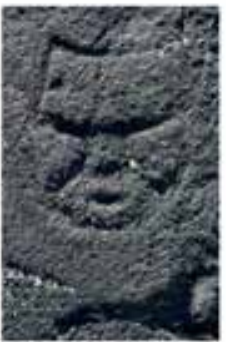

Open-mouth

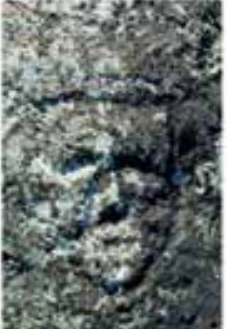

Shield

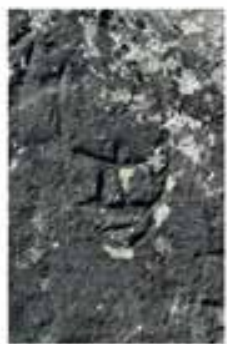

Horned-head

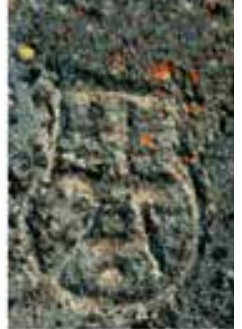

Pitcher

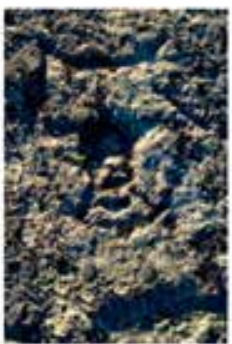

Animal-like

Figure 12. The petroglyphs made at Qajartalik allow to differentiate several types of faces, some looking humans, others more like animals and a few in between. It is likely that the artists wanted to show different stages in the "transfiguration" of a shaman (or his/her spirit-helper) so as to impress the people wandering through the site (photos by the author).

Figura 12. Los petroglifos hechos en Qajartalik permiten diferenciar varios tipos de rostros, algunos antropomorfos, otros más zoomorfos y unos pocos indiferenciados. Es probable que los artistas quisieran mostrar las diferentes etapas de la "transfiguración" de un chamán (o su guía espiritual) con el fin de impresionar a las personas que deambulan por el sitio (fotos del autor). 
many rock surfaces, some with the additional features mentioned-pointy ears or straight lines protruding from under the chin (figs. 11 and 12; Arsenault 2007a). At Qajartalik, then, we have an interesting spectrum of faces ranging from the more human-like to the more animallike in appearance. Accordingly, if this archaeological site was used for shamanic purposes at least some of the time, and the rock art was created to express that shamanistic context, then the engraved faces may have been produced to depict a particular stage of the shamanic transformation associated with a trance experience.

As noted above, the petroglyphs at Qajartalik depict faces shown only from a frontal perspective, which creates a very impressive overall visual effect on onlookers wandering through the site, as one can be overwhelmed by coming literally "face to face" with some of those figures or "surrounded" by several at a time when standing in a particular spot. Even more impressive would be to come upon those faces, either suddenly or gradually, in a shamanistic context; initiates, for instance, could have used this feature to make a visual impact on novices as the secret knowledge of the shaman was transmitted to them. Furthermore, if the Dorset people intended all of these petroglyphs to participate in the reception of that sacred message, then the marks left by the quarrying tools on the rock outcrops, the preliminary outline of an oil-lamp, and even natural elements such as the lichens, the various colours of the rock, the soil and the plants linked to the engraved symbols cannot be ignored, as they may have added to the general effect produced by the visual display of the site's main graphic elements (fig. 13). Is it too far-fetched to consider, then, that these human-made markings and the natural elements left on the rock surfaces at Qajartalik may have established a symbiotic relationship between two forms of expression-the mundane and the spiritual, the tangible and the intangible, the profane and the sacred, nature and culture, merging together in that very place to create a unique aesthetic environment proper to that rock art site? At any rate, with this first criterion in hand, the question offers an interesting possible interpretation of how the complexity of the site's specific visual features may have occasionally contributed to the aesthetic power of Qajartalik.

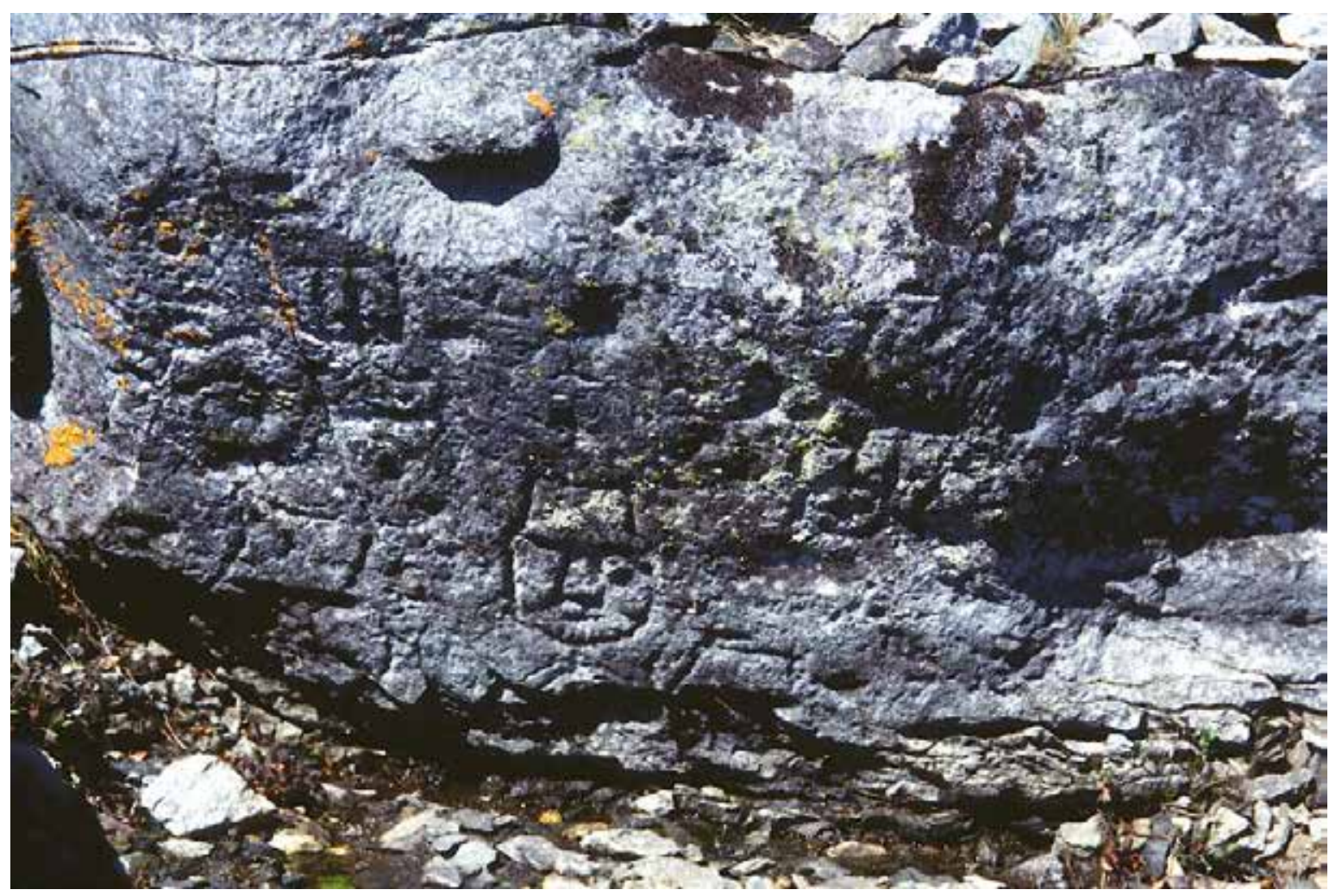

Figure 13. A combination of petroglyphs, extraction zones, preforms of containers, the relief, colors and textures of the rock outcrops surfaces and surrounding soil, the plants, the lichens and the waterholes altogether may have contributed to the visual effects characterising Qajartalik (photo by the author).

Figura 13. En conjunto la combinación de los petroglifos, las zonas de extracción, las preformas de envases, el relieve, los colores y las texturas de las superficies de los afloramientos de roca y de suelo circundante, las plantas, los líquenes y los pozos de agua, puede haber contribuido a los efectos visuales que caracterizan a Qajartalik (foto del autor). 
The rock outcrops and the layout of petroglyphs

The visual symbols themselves, the distinctive topography of the rock outcrops at Qajartalik and the layouts of the petroglyphs they hold are all worthy of mention. The rock faces bearing the petroglyphs are vertical, horizontal or more or less oblique, and depending on their general orientation, their exposure to sunlight or moonlight can vary significantly. Consequently, some of the decorated surfaces-especially the ones with the most images and those with deeper and larger grooves-may have been easier to see during the day or during full moon nights. In contrast, there are also a few engravings that must have gone unnoticed, as they remain in the shade almost all the time due to the northern orientation of their rock supports.

Furthermore, the volume and shape of those multifaceted rocks protruding from the ground are impressive in themselves, especially when the sun shines on them and creates a play of lights and shadows in the rift where they lie. Then, they look like massive structures that one can stand on (fig. 14). The location of the rock outcrops, nestled in a geological fault, enhances their massiveness and impressiveness, particularly when one looks down on them from above when standing or walking along the upper edge of the rift, or when one wanders around their bases on the ground. The irregularity of the terrain forces visitors to discover the place and its graphics gradually by walking in and around them or standing at an observation point. Under such conditions, visitors cannot ignore the uniqueness of each carved panel and may even be awestruck at times, such as when a series

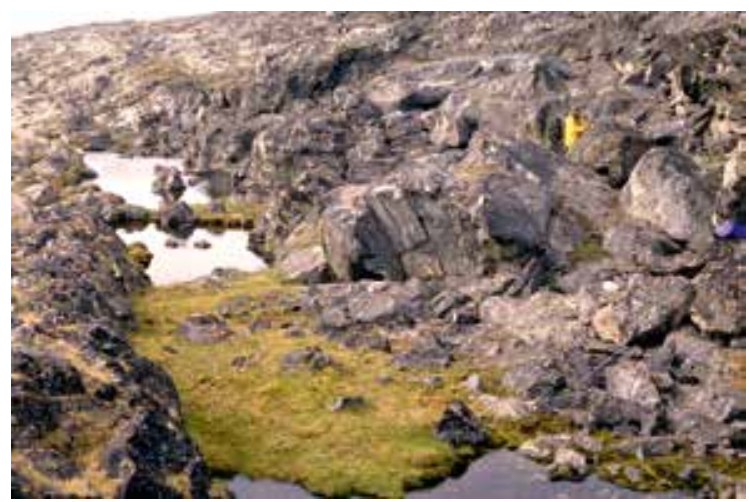

Figure 14. Through their respective location, volume, shape and size, the rock outcrops on the site may have helped to increase the aesthetic emotion of the onlooker at Qajartalik (photo by the author). Figura 14. A través de su respectiva ubicación, volumen, forma y tamaño, los afloramientos de roca en el sitio pueden haber contribuido a aumentar la emoción estética del espectador en Qajartalik (foto del autor). of engraved faces suddenly appears on a rock support, lit up by the suns rays or the silver light of a full moon. Perhaps the Dorset people, who likely saw the world as animated, looked upon those rocky structures through such a spiritual filter. Maybe they perceived the ornate rock outcrops plainly as some living creatures, full of power with the many faces engraved on them, looking like animated entities, the Torngait, with whom they had to communicate at close range and therefore wanted to manage those exchanges with care, materially as well as symbolically. However, when the Dorset people disappeared and the Thule took their place, the newcomers appear to have been less impressed by the place than their predecessors; for not only did they not produce any new petroglyphs, they actively quarried the site and even destroyed some engraved faces to make their stone vessels. ${ }^{6}$

\section{The physical setting, vistas and scenery}

By extension, it is the physical setting of Qajartalik that itself becomes important for its aesthetics. The elongated fault around its edges accentuates the relationship between the engraved rock outcrops, the grassy ground and the waterholes, creating a network of pathways that must be followed carefully. Wandering along those pathways, visitors can then focus their attention on the concentrations of petroglyphs and their rocky supports. However, when arriving at the site, visitors are not totally freed from action, as they have to walk along these natural pathways until they can climb up on the major rock outcrops. All of these different pathways, including those on top of the main rock formations, offer visitors the chance to stop at different observation points, where they can examine the site's archaeological components and natural features in detail, particularly the rock art and other human-made marks left on the many rocky surfaces available. Indeed, the vistas to be taken advantage of are many.

On a larger scale, the scenery at Qajartalik is breathtaking, and depending on where you stand, you can look either inside the geological rift where the archaeological site is situated and at the sectors within, including where the petroglyphs can be seen, or around the site and into the distance to the sea, the sky and the adjoining island, Qikertaaluk, and beyond that to the coast and mountains of the Ungava Peninsula (fig. 15). Additionally, when wandering within the site itself, on the ground and around the rock outcrops, you can feel somewhat isolated, but when you move from Sector 4 to Sector 1 along the site's longitudinal axis and climb on top of the main decorated outcrops in Sectors 2 


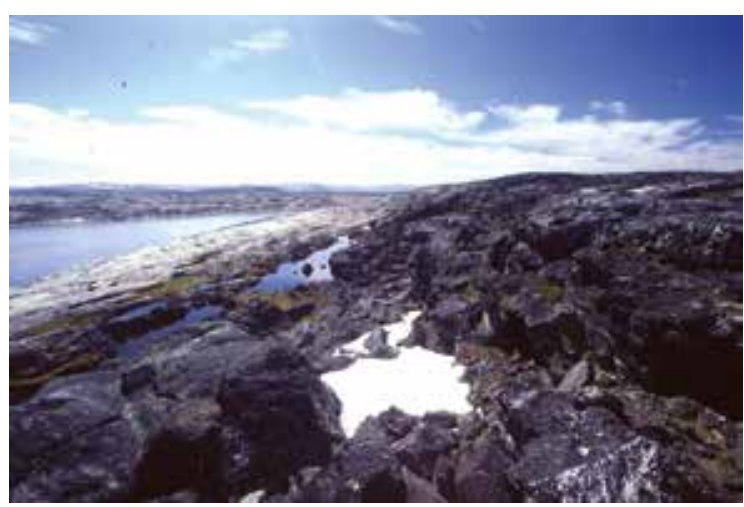

Figure 15. From Qajartalik, any onlooker can have a breath taking view of the general landscape, including the rockscape and the seascape which, along with the sky, represent visual elements enhancing the aesthetic experience of the place (photo by the author). Figura 15. Cualquier espectador puede tener una magnífica vista del paisaje general de Qajartalik, incluyendo el paisaje rocoso y el paisaje marino que, junto con el cielo, representan elementos visuales que mejoran la experiencia estética del lugar (foto del autor).

and 3, or climb up and walk along the edge of the geological fault, you become aware of the surrounding environment and feel closely a part of it, with the sky, the wind and the rain adding to your impression of the moment as the experience is lived in situ. All of these impressions become what we can interpret as a phenomenological experience per se as well as a "sensual" one, provoking an aesthetic emotion that past visitors would have also enjoyed momentarily, whatever their culture and Weltanschauung.

Indeed, a good place to stand for a while is within the rock shelter at one end of the site where an artificial platform was built in the past, about $1.5 \mathrm{~m}$ above ground level. ${ }^{7}$ When a person is seated within the rock shelter, observation of the petroglyphs is difficult, because the closest engraved rock outcrop is too far away to identify the images. All the rock outcrops, their layouts, the ground with its ponds (when the water has not completely disappeared at the end of the short summer season!) and the inner walls of the fault work together to create an overall configuration. This configuration and the views over the surrounding landscape (which includes, in the foreground, the slopes of Qikertaaluk Island rolling down to the bay and, in the background, the sea, the coast of the Ungava Peninsula and the mountains) combine to create a very strong impression on all who come here, for the scenery is just spectacular.

This kind of aesthetic experience can capture the imagination of the onlooker. Now, the name Qajartalik makes reference to the kayak, and indeed, the elongated shape of the geological rift in which the site is inscribed outlines what appears to be the shape of that small Arctic vessel. Although we do not know whether the Dorset people saw the shape in the same way, we can speculate that they did, given that the kayak was the only watergoing mode of transportation in use in their time, and continued to be used by the Thule and Inuit peoples thereafter. So, with a little imagination, visitors can also feel as though they are seated in a giant kayak. Did the ancient visitors to the site feel the same way? Perhaps...

\section{Ambient natural and artificial phenomena}

Lastly, what ambient phenomena can we include in the aesthetic appreciation of visitors past and present to the site of Qajartalik? The first conditions that one encounters when walking at the site-and certainly the easiest to confirm on a daily basis-are those caused by the natural light, and not only the ever-changing effect of the sun or even the moon's passage across the sky, but also the conditions brought to bear when the sky is cloudy. Other conditions must also be considered, such as those enabled by ambient sounds produced by natural elements such as strong wind, rain and the sound of the waves breaking on the rocky shorelines at high tide about $15 \mathrm{~m}$ from the site. These varied sound and light effects can be considered part of the phenomenology of Qajartalik, and as such can be taken into account in relation to its aesthetics, for no doubt the current conditions also held true in ancient times, and at least some of them would have been experienced by those who visited the site in those remote times. ${ }^{8}$

As discussed briefly above, the interplay between light and shadow may have been a factor that emphasized the special visual qualities of the site, including its aesthetics. For instance, on a clear, sunny day, the dynamic interplay of light and shadow creates an ever-changing light show on the rock surfaces that causes many of the faces to appear then disappear as the day progresses, leaving visitors in awe of the sudden manifestation of the intangible turned sensible as it is provoked by so many strange figures. The same thing occurs with the "moving shapes" of the decorated rock outcrops themselves on sunny days and full moon nights. And one cannot ignore another visual effect, which might have played an active role in the Qajartalik aesthetic experience: the reflection of objects and people on the surface of the ponds. This too is part of the "seen-unseen" interplay proper to the creation of a "world of illusions," and is especially appropriate in a shamanistic context.

By the same token, I believe that the site's acoustics may have also participated in this singular "sensible 
experience of the place" by offering a series of sound impressions to those who spent some time at Qajartalik. For instance, the constant sound of the waves breaking on the shore, or occasional sounds such as the wind, which sometimes blows very strongly over the island and the sea, or even those made by certain animals, such as the singing of flocks of birds, can be amplified or diminished, depending on where one stands within the site. As many studies in the anthropology of religion have pointed out (Arsenault 1999), any spiritual experience, and in particular any collective ritual, can be easily enhanced by unusual audible effects. In this regard, one also cannot ignore the possibility that some artificial sounds might have been produced at the site in the past to enhance the ritual experience of those participating. Certain songs and the rhythmic sound of musical instruments like drums can induce the "altered state of mind" favourable for experiencing what is transmitted during a ritual performance, but they also make the context even more impressive. Again, if Qajartalik was a special place imbued with a shamanistic tone, at least during the Dorset Period, it is likely that artificial sounds such as these, along with natural ones, would have been made on purpose by those directing the activities, in order to intensify the participants' feelings as they observed the petroglyphs and the rock outcrops. In other words, sounds, whether usual or unusual, natural or artificial, may have been part of the "ritual drama" (Turner 1979) played out as the Dorset ritual actors performed at that unique engraved quarry. Indeed, a more detailed, systematic reading of the acoustics present year-round at Qajartalik, including a scientific recording protocol (see Waller \& Arsenault 2008), is needed so as to effectively document and confirm more objectively these initial observations on the sound ambience of the site.

\section{CONCLUSION}

It takes but a few descriptions of the aesthetic qualities of Qajartalik to show that onlookers, either present or past, could have had a special aesthetic experience here, particularly during the summertime when the geological rift is devoid of snow. It is reasonable to suppose that anyone visiting Qajartalik in the past would have been impressed or even spellbound by the majestic panorama he or she encountered, as well as by the site's components and its breathtaking setting. Now, considering the Dorset spiritual context and its shamanistic roots, one can ask whether those qualities of this unique site might have heightened the perceptions and feelings of those who were to be trained in this spiritual sphere. If so, would this experience not have enhanced the participants' appreciation and understanding of the site's sacredness and the aesthetic qualities of its petroglyphs in relation to the Spirits of the place, the Torngait? This is the point I wished to bring sharply to the fore through this brief aesthetic analysis. If Qajartalik was used by the Dorset people as a quarry, is it too farfetched to think that these ancient people were inspired to use the aesthetic properties of the site to appropriate and transform that place in order to initiate younger members of the group into the sacred shamanic knowledge, or at least into their Weltanschauung? Let us imagine, for instance, a rite of passage performed in Dorset times, in which a novitiate wandered around the engraved rock outcrops. Would it make it easier to instruct this young person in the secret and sacred nature of the place by strategically using-especially through the subtle orientation of his or her gaze over the rock outcrops-the magical appearance and disappearance of the faces and the impressiveness of their rock support, not to mention both the spectacular vistas of the surrounding natural environment and the sounds that could be heard (or made) there? I believe so, but more research is needed to advance this work in progress.

At any rate, the situation may have changed significantly when the Thule people and then the Inuit appropriated the site for their own purposes, which centered on quarrying activities. Neither group seems to have taken advantage of the aesthetic dimensions of Qajartalik as their predecessors did, and they produced only stone vessels, even though the same natural conditions still prevailed that would have made it possible to trigger an aesthetic emotion in visitors to the site. Evidently, these later groups did not "seize the day", but rather affirmed that well known French phrase, autre temps, autres moeurs ("other times, other customs")! It might be that, despite the universality of some aspects of aesthetics, the subtle appreciation of certain natural and cultural features still depends to some extent on a series of culturally sensitive constraints, even inhibitions, and the Thule and Inuit actors apparently differed significantly from their remote Dorset ancestors in this regard.

In any case, from an archaeological perspective it is obvious that the relationship between a site's graphic content and other physical, visual and audible features linked to its setting can create a network of meanings that has to be not only understood but also experienced through the senses in the present in order to aesthetically define what could have made the place so special in the past. As Mairi Ross wrote: "By contextualizing rock art within the landscape and incorporating the dimensions of movement, sound, touch and other states of 
consciousness into our interpretations, we move closer and closer to recreating the world of the hunter-gatherers, and thereby closer and closer to understanding the messages they left behind." (Ross 2001: 547) In this regard, by applying this archaeo-aesthetic analytical framework to the Dorset Culture and history, I sought to bring to light sufficient information about the singular aesthetic qualities of Qajartalik for such a hunter-gatherer people. Furthermore, the four criteria I have proposed in this text can be applied to an aesthetic analysis of any rock art site in the world, enabling us to better embrace its singular past and present beauty as well as to interpret, and eventually "re-present" (see Arsenault \& Gagnon 2002 for a discussion surrounding the future heritage use of Qajartalik) the ways in which its aesthetic dimension may have been or even be part of the human experience of the place for any society, ancient or modern.

\section{NOTES}

${ }^{1}$ This assumption was soon to be substantiated with a comparative analysis performed by an archaeologist, William E. Taylor, and an art historian, George Swinton (Taylor \& Swinton 1967), and much later by a rock art specialist, Paul Taçon (1993), showing that a stylistic approach can be fruitful for some specific cases when one wishes to better situate rock art within an established archaeological timeframe.

${ }^{2}$ The art production of the Thule people was different to a degree from their indirect forebears (McGee 1987; Crandall 2000), and notably because, as far as we know, they did not leave any rock art.

${ }^{3}$ Although Saladin d'Anglure reported that Qajartalik's steatite had been evaluated by modern Inuit sculptors in search of a goodquality soapstone and that some did extract that raw material in modern times, he never really paid attention to the ancient quarrying zones, and therefore never stated that that site might have been also used by prehistoric quarrymen for the making of containers and other utilitarian goods.

${ }^{4}$ When one compares some of these hybrid faces with Dorset figurines, the pointed ears or the horns can be in fact the simplified representation-because the outlines on these engravings are in continuity with the rest of the facial silhouette-of the corners of a raised hood that the Dorset people seemed to have worn, but in some other cases, the engraved faces clearly show a mixture of human and animal facial traits.

${ }^{5}$ http://www.vanishingtattoo.com/arctic_tattoos.htm, consulted February 16th, 2013.

${ }^{6}$ In particular, the shape of their oil-lamps was rectangular rather than oval, and they were significantly bigger than Dorset lamps, usually above 30 centimeters in length compared to less than 10 centimeters long (Langlais 2007, 2010).

${ }^{7}$ An excavation in 1997 at that rock shelter did not discover any archaeological material which could have helped to evaluate the age of that artificial platform; it only yielded a scapula of a seal, perhaps a sacrificial offering or the remains of a meal, but no trace of fire. So we do not know whether that platform was built by the Dorset, by the Thule or by the Inuit people, although we did notice that it was a rudimentary structure allowing only two or three people to be seated comfortably within the rock shelter and perhaps rest a little for a short period of time (Arsenault et al. 1998).

${ }^{8}$ I do not include in this analysis some other sensitive elements coming from nature, such as the salty perfume of the sea, the scent coming from the wet ground or from the waterholes within the rift, the increased humidity of the air at the end of a rainy day as well as the freezing weather of the place during a part of the year, and its counterpart, the brief warm weather of the short summertime when the sun shines. All these elements might also have participated in this phenomenological experience at Qajartalik in ancient times, and should not be neglected in a thorough archaeo-aesthetic analysis.

\section{REFERENCES}

Arsenault, D., 1999. Rite et pouvoir: Perspectives anthropologique et archéologique. Anthropologie et sociétés 23 (1): 1-17, Québec. 2005. From real to virtual... The Potential for better recording a unique rock-art site in the Canadian Arctic. <http://cipa.icomos. org/fileadmin/template/doc/TURIN/1003.pdf> [Citado 04-12-13]. 2007a. Nouveau regard archéologique sur d'anciennes figures gravées. Les pétroglyphes du site de Qajartalik, Nunavik. In Des Tuniit aux Inuits: Patrimoines archéologique et historique au Nunavik, D. Arsenault \& D. Gendron, Eds., pp. 215-233. Québec and Montréal: CÉLAT.

- 2007b. Introduction. In Des Tuniit aux Inuits: Patrimoines archéologique et historique au Nunavik, D. Arsenault \& D. Gendron, Eds., pp. 17-19. Québec and Montréal: CÉLAT.

— 2007c. Tuniit, Torngait et diablotins... Réception ambivalente de l'art rupestre dorsétien par l'Inuit et le Qabloonaq. In Nords imaginaires, D. Chartier, Ed., pp. 185-206. Montréal: Presses de l'Université du Québec.

ArSEnAult, D. \& L. GaGnon, 2002. These faces are still looking at us, but are they laughing at us? Typological, kinesic, and proxemic analysis of the Dorset petroglyphs of Qajartalik, Nunavik. In Visio 8 (1-2): 29-34. Québec: Association Internationale de Sémiologie Visuelle (AISV).

Arsenault, D.; L. GaGnon \& D. Gendron, 1998. Investigations archéologiques récentes au sud de Kangirsujuaq et sur le site à pétroglyphes de Qajartalik, détroit d'Hudson, Nunavik. Études/ Inuit/Studies 22 (2): 77-115. Québec: Université Laval.

Arsenault, D.; L. GaGnon, D. Gendron \& C. Pinard, 2005. Kiinatuqarvik, A Multidisciplinary Archaeological Project on Dorset Petroglyphs and Human Occupation in Kangirsujuaq Area. In Contributions to the Study of the Dorset Palaeo-Eskimos (Mercury Series, Archaeology Paper $N^{\circ}$ 167), P. D. Sutherland, Ed., pp. 105-120. Gatineau: Canadian Museum of Civilization.

Bruemmer, F., 1973. The Petroglyphs of Hudson Strait. The Beaver 304 (1): 33-35, Ottawa.

Chippindale, C. \& G. Nash (Eds.), 2004. The Figured Landscapes of Rock Art. Looking at Pictures in Place. Cambridge: Cambridge University Press.

Crandall, A. R., 2000. Prehistoric Inuit art. In Inuit Art. A History, R. C. Crandall, Ed., pp. 13-20. Jefferson: McFarland and Company inc.

Francis, J. E., 2001. Style and classification. In Handbook of Rock Art Research, D. S. Whiltey, Ed., pp. 221-244. Walnut Creek: AltaMira Press.

Gendron, D.; D. Arsenault \& L. GaGnon, 1996. À propos du projet de sauvetage des pétroglyphes de Qajartalik. Réplique à la lettre de M. Patrick Plumet. Études/Inuit/Studies 20 (2): 117-122. Québec: Université Laval.

Gagnon, L.; A. Bergeron, M. Aubert \& D. Arsenault, 2007. Qajartalik: péril en la demeure, mythe ou réalité? Bilan des recherches en conservation à la carrière à pétroglyphes de Qajartalik (JhEv-1). In Des Tuniit aux Inuits: Patrimoines archéologique et historique au Nunavik, D. Arsenault \& D. Gendron, Eds., pp. 249-263. Québec and Montréal: CÉLAT.

GrønNow, B., 2012. The Backbone of the Saqqaq Culture: A Study of the Nonmaterial Dimensions of the Early Arctic Small Tool Tradition. Arctic Anthropology 49 (2): 58-71. California: University of Davis-California.

Hannigan, J. A., 2005. Proxemics, kinesics, and gaze. New Handbook on Methods in Nonverbal Behavior Research: 137-198. Oxford: Oxford University Press. 
Helmer, J. W., 1986. A Face from the Past: An Early Pre-Dorset Ivory Maskette from Devon Island, N.W.T. Études/Inuit/Studies 10 (1-2): 179-202. Québec: Université Laval.

Heyd, T., 2005. Aesthetics and Rock Art: An introduction. In Aesthetics and Rock Art, T. Heyd \& J. Clegg, Eds., pp. 1-19. Aldershot: Ashgate.

— 2012. Rock "Art" and Art: Why aesthetics should matter In A Companion to Rock Art, J. MacDonald \& P. Veth, Eds., pp. 276-293. Chichester: Blackwell Publishing.

Heyd, T. \& J. Clegg (Eds.), 2005. Aesthetics and Rock Art. Aldershot: Ashgate.

Jimenez, M., 1997. Qu'est-ce que l'esthétique? Paris: Gallimard.

LANGLAIS, A., 2007. Étude des modes d'extraction à la carrière de stéatite de Qajartalik (JbEv-1). In Des Tuniit aux Inuits: Patrimoines archéologique et historique au Nunavik, D. Arsenault \& D. Gendron, Eds., pp. 235-248. Québec and Montréal: CÉLAT. 2010. Reconstitution des modes d'extraction de la stéatite sur le site de Qajartalik. Montréal: Avataq Cultural Institute (Publications en archéologie du Nunavik / Nunavik Archaeology Monograph $\mathrm{N}^{\circ} 3$ ).

McGhee, R., 1987. Prehistoric Arctic Peoples and their Art. American Review of Canadian Studies 17 (1): 5-14. Washington, DC.

- 1996. Ancient People of the Arctic. Vancouver: University of British Columbia Press.

Plumet, P., 1996. À propos du sauvetage des pétroglyphes dorsétiens de Qajartalik dans le Nunavik (Arctique québécois) - Quelques réflexions sur la politique de l'archéologie dans le Nunavik. Études/Inuit/Studies 20 (2): 112-116. Québec: Université Laval.

- 1997. L'Importance archéologique de la Région de Kangirsujuaq au Nunavik (Arctique québécois): Un centre chamanique dorsétien? In Fifty Years of Arctic Research, R. Gilberg \& H.
C. Gullov, Eds., pp. 249-260. Copenhague: Publication of The National Museum of Denmark (Ethnographical Series 18).

Ross, M., 2001. Emerging trends in rock-art research: Hunter-gatherer culture, land and landscape. Antiquity 75: 543-548, Durham.

SALADin D'ANGlure, B., 1962. Découverte de Pétroglyphes à Qajartalik sur l'île de Qikertaaluk. North/Nord 9 (6): 34-39, Ottawa.

— 1963. Discovery of Petroglyphs near Wakeham Bay. The Arctic Circular 15 (1): 6-13, Toronto.

— 1965-1966 Ms. Rapport succinct sur le travail effectué au cours de l'été 1965 pour le Musée national du Canada. Unpublished report housed at Library and Archives Canada, Ottawa.

SutHerland, P., 2001. Shamanism and the iconography of the PalaeoEskimo Art. In The Archaeology of Shamanism, N. Price, Ed., pp. 133-145. London and New York: Routledge.

TAÇON, P. S., 1993. Stylistic Relationship Between the Wakeham Bay Petroglyphs of the Canadian Arctic and Dorset Portable Art. In Rock Art Studies: The Post-Stylistic Era or Where Do We Go From Here? M. Lorblanchet \& P. C. Bahn, Eds., pp. 151-162. Oxford: Oxbow Books.

Taylor, W. E. \& G. Swinton, 1967. Prehistoric Dorset Art. The Beaver 298: 32-47, Ottawa.

Turner, V., 1979. Dramatic Ritual/Ritual Drama: Performative and Reflexive Anthropology. The Kenyon Review (New Series) 1 (3): 80-93. Gambler: Kenyon College.

Waller, S. \& D. Arsenault, 2008. Echo Spirits who paint rocks: Memegwashio dwell within echoing rock-art site Eigf-2, Nemiscau Lake (James Bay area, Québec). American Indian Rock Art 34: 191-201. Phoenix: American Rock Art Research Association (ARARA).

Whitley, D. S. (Ed.), 2001. Handbook of Rock Art Research. Walnut Creek: AltaMira Press. 